\title{
STUDIES ON THE SILVER VOLTAMETER
}

\author{
By G. A. Hulett and G. W. Vinal
}

\section{INTRODUCTION}

At the suggestion of Prof. E. B. Rosa, of the Bureau of Standards, a comparison has been made of the silver voltameters and methods employed at the Bureau of Standards with the voltameters and methods used at Princeton University by Prof. Hulett and his coworkers. In January, I9I4, one of the authors (G. W. Vinal) therefore went to Princeton with part of the Bureau of Standards equipment of voltameters.

This work was intended to include a comparison of the methods of preparing the electrolyte, of the porous cups and their manipulation, of the methods of washing and weighing the deposit, and of other details of operation in order to find an explanation for certain differences in conclusions reached and to see whether when the electrolyte was pure and the manipulation the same, the voltameters, which were of different sizes and shapes, would give identical results. In addition, it was planned to study the question of inclusions in the deposit if time permitted.

This program was in the main carried out except for the matter of the inclusions, for which, owing to unexpected developments in some of the other work, there was not sufficient time. It seems worth while to call attention to these new developments at the present time.

Throughout the following discussion the apparatus and methods which have heretofore been used and described by Prof. Hulett and his students are designated as the Princeton apparatus or method. Similarly, also, we shall refer to the Bureau apparatus and methods as previously described in the recent publications of the Bureau of Standards on this subject. 


\section{COMPARISON OF THE VOLTAMETERS}

\section{PRELIMINARY WORK}

A preliminary comparison of the voltameters was made in four experiments (of which the first is designated as a trial experiment) to determine the relation of the Princeton voltameters with those of the Bureau of Standards. In each case the voltameters were assembled and treated in accordance with the customary procedure. But the electrolyte used in all the voltameters of any experiment was always the same, ${ }^{1}$ so that we have a comparison of the voltameters themselves not involving any differences due to the preparation of the silver nitrate. The voltameters were all of the porous-cup variety. ${ }^{2}$

\section{TABLE 1}

Preliminary Comparison of Voltameters

[Nos. 27 and 28 are Bureau of Standards voltameters; I and II are Princeton voltameters]

\begin{tabular}{|c|c|c|c|c|}
\hline Date & Cup & Deposit & Mean & $\begin{array}{l}\text { Difference, } \\
\text { B. S.-Princ. }\end{array}$ \\
\hline $\begin{array}{c}1914 \\
\text { Feb. } 18\end{array}$ & $\begin{array}{r}27 \\
28 \\
\text { I } \\
3 \text { II }\end{array}$ & $\begin{array}{c}\underset{4103.34}{\mathrm{mg}} \\
(4102.94) \\
\ldots \ldots \ldots \ldots . . \\
4103.12\end{array}$ & $\begin{array}{c}\mathrm{mg} \\
4103.34 \\
4103.12\end{array}$ & $\frac{+5.4}{100000}$ \\
\hline Feb. 26 & $\begin{array}{r}27 \\
28 \\
\text { I } \\
\text { II }\end{array}$ & $\begin{array}{l}4090.84 \\
4090.90 \\
4090.39 \\
4090.47\end{array}$ & $\begin{array}{l}4090.87 \\
4090.43\end{array}$ & $\frac{+10.7}{100000}$ \\
\hline Mar. 7 & $\begin{array}{r}27 \\
28 \\
\text { I } \\
\text { II }\end{array}$ & $\begin{array}{l}4118.32 \\
4118.36 \\
4117.54 \\
4117.68\end{array}$ & $\begin{array}{l}4118.34 \\
4117.61\end{array}$ & $\frac{+17.7}{100000}$ \\
\hline Mar. 20 & $\begin{array}{r}27 \\
28 \\
\text { I } \\
\text { II }\end{array}$ & $\begin{array}{l}4094.55 \\
4094.55 \\
4094.23 \\
4094.24\end{array}$ & $\begin{array}{l}4094.55 \\
4094.23_{5}\end{array}$ & $\frac{+7.7}{100000}$ \\
\hline Mean & & & & $\frac{+10.4}{100000}$ \\
\hline
\end{tabular}

I This electrolyte was prepared according to the methods of the Bureau of Standards. This Bulletin, $\mathbf{9}$, p. 524 .

2 Details of construction of these voltameters are given in Trans. Am. Electrochem. Soc., 12, p. 257; 22 , p. 367 ; and this Bulletin, 9, p. I5I.

${ }^{3}$ Vacuum dried; all others dried by heating to $160^{\circ}$. 
The values are given in Table $\mathrm{I}$. On the average the deposits in the Bureau voltameters exceeded those in the Princeton voltameters by about ro parts in 100 000 .

A systematic search was now begun for the cause of this difference. In Table 2 we give the physical aspects of the voltameters employed.

Differences in the method of washing the deposits proved to be important and without doubt influenced the results given in Table I. We shall describe under the heading "Washing the deposits" the experiments which we made in this connection. The essential fact here is that according to the Princeton method the voltameters always stood overnight filled with distilled water, while the Bureau procedure has been to complete the washings of the deposit at once, unless the lateness of the hour made it convenient to allow the cups to remain filled with water overnight. This was a most unexpected result and on examining the matter carefully we have discovered that when water is allowed to stand on silver which has been deposited on platinum a slow and progressive loss of silver takes place. During the interval between closing work for one day and beginning the next the loss is appreciable in amount.

Comparative determinations of the acidity of the electrolyte for the various voltameters before and after the electrolysis showed the following results. These were made according to the method described by Rosa, Vinal, and McDaniel, ${ }^{4}$ except that methyl red was employed as an indicator instead of iodeosine, because it is much more convenient to use and seems to be equally reliable.

TABLE 2

\section{Comparison of the Physical Aspects of the Voltameters}

[Nos. 27 and 28 are Bureau of Standards voltameters; I and II are Princeton voltameters. Platinum cathodes were used throughout]

\begin{tabular}{|c|c|c|c|c|c|c|c|c|c|}
\hline \multirow{2}{*}{ No. } & \multicolumn{4}{|c|}{ Cathodes } & \multirow{2}{*}{ Anodes } & \multicolumn{4}{|c|}{ Porous cups } \\
\hline & Depth & $\begin{array}{c}\text { Diam- } \\
\text { eter }\end{array}$ & $\begin{array}{c}\text { Capac- } \\
\text { ity }\end{array}$ & Surface & & $\begin{array}{c}\text { Manufac- } \\
\text { ture }\end{array}$ & $\begin{array}{l}\text { Diam- } \\
\text { eter }\end{array}$ & Depth & Treatment \\
\hline & $\mathrm{cm}$ & $\mathrm{cm}$ & cc & & & & $\mathrm{cm}$ & $\mathrm{cm}$ & \\
\hline 27 & 7 & 6 & 125 & Bright.. & Electrolytic. & German... & 3.8 & 5.8 & Kent in ArNO \\
\hline 28 & 7 & 6 & 125 & ...do..... & ..... do... & ...do........ & 3.8 & 5.8 & 3 \\
\hline I & 10 & 5 & 165 & Matte... & Cast.... & American. & 2.5 & 12.0 & $\int$ Kept in $\mathrm{H}_{2} \mathrm{O}$; \\
\hline II & 10 & 5 & 165 & ...do..... & .....do... & ...do......... & 2.5 & 12.0 & $\left\{\begin{array}{l}\mathrm{rinsed} \text { with } \\
\mathrm{AgNO}_{3} \text { before use }\end{array}\right.$ \\
\hline
\end{tabular}

4 This Bulletin, 9, p. $5^{26}$. 
The acidity measurements are given in Table 3 .

\section{TABLE 3}

Changes in Acidity of Electrolyte for the Preliminary Experiments

[Nos. 27 and 28 are Bureau of Standards voltameters; I and II are Princeton voltameters]

\begin{tabular}{|c|c|c|c|c|c|}
\hline Date & Cup & Initial acidity & $\begin{array}{c}\text { Final cathode } \\
\text { acidity }\end{array}$ & $\begin{array}{c}\text { Increase, } \mathrm{B} . \mathrm{S} . \\
\text { cups }\end{array}$ & $\begin{array}{l}\text { Increase, } \\
\text { Princeton cups }\end{array}$ \\
\hline 1914 & & & & & \\
\hline \multirow{4}{*}{ February $18 \ldots \ldots \ldots \ldots \ldots \ldots$} & 27 & $0.5 \times 10^{-6}$ & $1.2 \times 10^{-6}$ & $0.7 \times 10^{-8}$ & \\
\hline & 28 & $0.5 \times 10^{-6}$ & $2.1 \times 10^{-6}$ & 1. $6 \times 10^{-6}$ & \\
\hline & I & $0.5 \times 10^{-6}$ & ….... & & \\
\hline & II & $0.5 \times 10^{-6}$ & ........ & 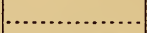 & \\
\hline \multirow[t]{4}{*}{ February $26 . \ldots \ldots \ldots \ldots \ldots$} & 27 & $0.9 \times 10^{-6}$ & $1.9 \times 10^{-6}$ & $1.0 \times 10^{-6}$ & \\
\hline & 28 & $0.9 \times 10^{-6}$ & $2.1 \times 10^{-6}$ & 1. $2 \times 10^{-6}$ & \\
\hline & I & $0.9 \times 10^{-6}$ & & & \\
\hline & II & $0.9 \times 10^{-6}$ & $\ldots \ldots \ldots$ & ...... & \\
\hline \multirow[t]{4}{*}{ March $7 \ldots \ldots \ldots \ldots \ldots \ldots$} & 27 & $0.9 \times 10^{-6}$ & $2.3 \times 10^{-6}$ & $1.4 \times 10^{-6}$ & \\
\hline & 28 & $0.9 \times 10^{-6}$ & 2. $7 \times 10^{-6}$ & $1.8 \times 10^{-6}$ & ..$\ldots \ldots \ldots \ldots$ \\
\hline & I & $0.9 \times 10^{-6}$ & 15. $7 \times 10^{-6}$ & & $14.8 \times 10^{-6}$ \\
\hline & II & $0.9 \times 10^{-6}$ & $7.3 \times 10^{-6}$ & .......... & $6.4 \times 10^{-6}$ \\
\hline \multirow[t]{4}{*}{ March $20 \ldots \ldots \ldots \ldots \ldots \ldots$} & 27 & $0.6 \times 10^{-6}$ & $0.6 \times 10^{-6}$ & $0.0 \times 10^{-6}$ & ................ \\
\hline & 28 & $0.6 \times 10^{-6}$ & 1. $6 \times 10^{-6}$ & $1.0 \times 10^{-6}$ & ........ \\
\hline & I & $0.6 \times 10^{-6}$ & $4.6 \times 10^{-6}$ & ......... & $4.0 \times 10^{-6}$ \\
\hline & II & $0.6 \times 10^{-6}$ & $7.0 \times 10^{-6}$ & (.............. & $6.4 \times 10^{-6}$ \\
\hline Average.. & & & & $1.1 \times 10^{-6}$ & $7.9 \times 10^{-6}$ \\
\hline
\end{tabular}

It thus appears that the change in acidity of the electrolyte is appreciably greater in the case of the Princeton voltameters than in the Bureau of Standards voltameters. The reason for this appears to involve the question of the equilibrium of the porous cup and the silver nitrate solution. It will be noted in Table 2 that the method of treating the porous cups was different in the two cases. Our results showed that when the same procedure for preparing the two kinds of porous cups was employed they yielded the same results. The difference between the Princeton and the Bureau results is not, therefore, to be attributed to the fact that the porous cups were made by different makers ${ }^{5}$ and from different materials.

\section{FINAL COMPARISON OF THE VOLTAMETERS}

Working on the assumption that the difference between the Princeton voltameters and the Bureau voltameters was due partly

\footnotetext{
${ }_{5}^{5}$ Princeton voltameters contained porous cups made by John Maddock \& Son, of Trenton, N. J. The Bureau voltameters contained porous cups made by the Königliche Porzellan Manufaktur, of Berlin.
} 
to the differences in the length of time that the deposits were washed and partly to the difference in the method of preparing the porous cups, two experiments were made in which these differences were eliminated. The washings for all were done as expeditiously as possible, and the porous cups for the Princeton voltameters were put into silver nitrate solution the day before each experiment. This solution was changed several times, so that the equilibrium between the porous cup and the neutral solution might be as complete as possible and similar to the method of keeping the porous cups in silver nitrate, as has been done at the Bureau.

Table 4 gives the results of these two experiments in which some gold cathodes were also used, but we give here only the results of the platinum cathodes for comparison with Table $\mathrm{I}$. It can be seen from Table $I$ I that the results with the gold cathodes were equally concordant.

\section{TABLE 4}

\section{Final Comparison of Voltameters}

[Nos. 27 and 28 are Bureau of Standards voltameters; I and II are Princeton voltameters. All were dried by heating to $160^{\circ}$ ]

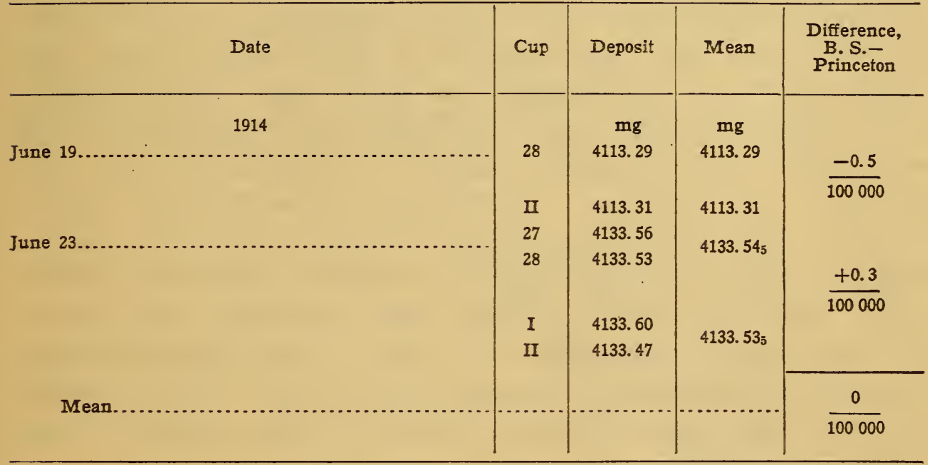

The values obtained in these last comparisons show very perfect agreement. The changes in acidities of the electrolytes also were about the same for the two forms of voltameter. The results of the acidity measurements made as before are given in Table 5 . 
TABLE 5

Acidities of Final Comparison of Voltameters

[Nos. 27 and 28 are Bureau of Standards voltameters; I and II are Princeton voltameters]

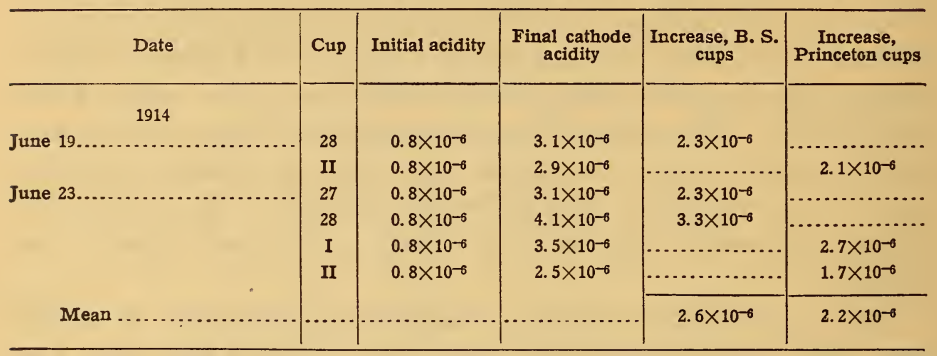

\section{WASHING THE DEPOSITS}

The practice of nearly all observers has been to continue the washing of the deposit until the presence of silver nitrate can no longer be detected in the wash waters by chemical tests, but many have taken the further precaution of allowing distilled water to stand on the deposit for a considerable period of time. In considering this matter we found the fact that chemical tests for the presence of silver was not particularly satisfactory when we were concerned with very small amounts of silver nitrate in the wash waters. In our final washings we were using "conductivity" water, and soon found that the change of conductivity of this water was a most admirable method for determining the completeness of the washing. The increases in conductivity, due to dissolved silver nitrate, were entirely reliable when we used a blank-that is, a clean platinum cup similarly filled with conductivity water and standing beside those containing the deposit. We could rapidly make tests of the water standing on the deposit and also that standing in the clean platinum cup. These observations showed a most unexpected state of affairs, which led to a special investigation.

It was found in the beginning that when conductivity water was put into the cups containing the deposits and allowed to stand only a short time that the increase in conductivity of the water was very small, provided of course that the silver deposits had been washed in the usual manner. This is illustrated by measurements 
on the final wash water for Nos. 27 and 28 in the experiment of March 8. This last water was allowed to stand on the deposits for five minutes.

Conductivity of water originally................. $0.98 \times 10^{-6}$ at $20^{\circ} \mathrm{C}$
Conductivity of water taken from No. $27 \ldots \ldots \ldots \ldots \ldots$ I. $00 \times 10^{-6}$ at $20^{\circ} \mathrm{C}$
Conductivity of water taken from No. $28 \ldots \ldots \ldots \ldots$ I. $05 \times 10^{-6}$ at $20^{\circ} \mathrm{C}$

It was found, however, that in the case of cups I and II of the same experiment which had been washed as thoroughly as Nos. 27 and 28 that the last water which stood in them overnight showed a distinct increase in conductivity.

After standing about ro hours we found:

Conductivity of water originally............... I. $44 \times 10^{-6}$ at $20^{\circ} \mathrm{C}$

Conductivity of water taken from I.............. $2.85 \times 10^{-6}$ at $20^{\circ} \mathrm{C}$

Conductivity of water taken from II............ $3.00 \times 10^{-6}$ at $20^{\circ} \mathrm{C}$

This increase in conductivity suggested that some silver nitrate was actually soaking out of the crevasses, but repetitions of this soaking process showed only small differences; that is, instead of the silver nitrate all coming out on continued washing so that the water could finally stand on the deposit without sensible change, as it does in a clean platinum cup, we found that the effect would repeat itself after a number of washings.

This effect is best illustrated by the measurements made on cups I and II of the experiment of April 4. These cups had been thoroughly washed five times, and also soaked overnight, before the measurements recorded below were begun. The following table shows the increases in conductivity observed in this case:

TABLE 6

\begin{tabular}{|c|c|c|c|c|c|}
\hline Date & Cup & $\begin{array}{l}\text { Number } \\
\text { of wash } \\
\text { water }\end{array}$ & $\begin{array}{l}\text { Duration } \\
\text { of } \\
\text { washing }\end{array}$ & $\begin{array}{c}\text { Increase } \\
\text { in } \\
\text { conductivity }\end{array}$ & $\frac{\text { Increase }}{\text { time }}$ \\
\hline 1914 & & & Hours & & $\times 10^{-6}$ \\
\hline \multirow{2}{*}{ 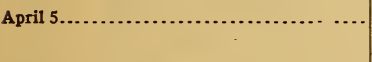 } & I & 7 & 10 & $1.03 \times 10^{-6}$ & 0.103 \\
\hline & II & 7 & 10 & $1.02 \times 10^{-6}$ & .102 \\
\hline \multirow{4}{*}{ April 6... } & I & 8 & 12 & 1. $23 \times 10^{-6}$ & $.102_{5}$ \\
\hline & III & 8 & 12 & $1.02 \times 10^{-6}$ & .085 \\
\hline & I & 9 & 12 & $1.25 \times 10^{-6}$ & .104 \\
\hline & II & 9 & 12 & $1.08 \times 10^{-6}$ & .090 \\
\hline \multirow[t]{2}{*}{ April 7.... } & I & 10 & $11 \frac{1}{2}$ & $1.09 \times 10^{-6}$ & .095 \\
\hline & II & 10 & $11 \frac{1}{2}$ & $1.05 \times 10^{-6}$ & .091 \\
\hline \multirow{2}{*}{$\begin{array}{l}\text { Mean I... } \\
\text { Mean I... }\end{array}$} & & & & & .101 \\
\hline & & & & & .092 \\
\hline
\end{tabular}

$86733^{\circ}-15-6$ 
In the case of each wash water that stood on the deposit overnight we could detect the presence of silver chemically by concentrating the solution in a platinum dish to about ro cc and testing it with potassium iodide. These tests were always conclusive and left no room for doubt that silver was actually in solution in the water.

In searching for an explanation of this phenomenon we allowed a sheet of pure silver to stand in conductivity water in a glass beaker which had been previously steamed and otherwise cleaned. The glass did not cause any significant increase in the conductivity of the water, as we had ascertained by previous experiment. When the silver was immersed in the conductivity water contained in this glass no change in conductivity was observed other than a very small, gradual increase due to contact of the air. The experiment was continued for 166 hours, and to confirm it we repeated it with another beaker and another piece of silver. The numerical results of these two experiments are given in Table 7 and plotted together as curve $I$ in Fig. I.

\section{TABLE 7}

[Conductivities corrected to $20^{\circ} \mathrm{C}$ ]

\begin{tabular}{|c|c|c|c|c|}
\hline Date & $\begin{array}{c}\text { Sam- } \\
\text { ple }\end{array}$ & Time & $\begin{array}{l}\text { Increase in } \\
\text { conductivity }\end{array}$ & Remarks \\
\hline 1914 & & Hours & & \\
\hline 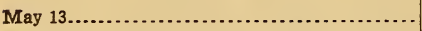 & $\mathbf{A}$ & 13 & $0.14 \times 10^{-6}$ & First water. \\
\hline May $15 \ldots . . . \ldots . . .$. & $\mathbf{B}$ & 23 & $0.12 \times 10^{-6}$ & Do. \\
\hline 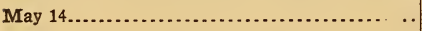 & $\mathbf{A}$ & 24 & $-0.05 \times 10^{-6}(?)$ & Second water. \\
\hline 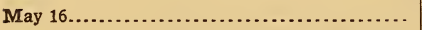 & $\mathbf{B}$ & 34. & $0.06 \times 10^{-6}$ & Do. \\
\hline 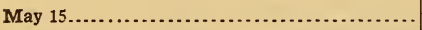 & $\mathbf{A}$ & 48 & $0.05 \times 10^{-6}$ & Do. \\
\hline May $18 \ldots \ldots \ldots \ldots \ldots \ldots$ & $\mathbf{B}$ & 70 & $0.04 \times 10^{-6}$ & Do. \\
\hline May $16 \ldots \ldots . . . . . . . .$. & $\mathbf{A}$ & 82 & $0.34 \times 10^{-6}$ & Do. \\
\hline May $18 \ldots \ldots \ldots \ldots$ & A & 118 & $0.13 \times 10^{-6}$ & Do. \\
\hline May $20 \ldots . . . . . . . .$. & $\mathrm{B}$ & 118 & $0.21 \times 10^{-6}$ & Do. \\
\hline Do & $\mathbf{A}$ & 166 & $0.35 \times 10^{-6}$ & Do. \\
\hline
\end{tabular}

Taking the final values, $0.35 \times 10^{-6}$ at 166 hours for $\mathrm{A}$ and $0.2 \mathrm{I} \times 1 \mathrm{I}^{-6}$ at $\mathrm{II} 8$ hours for $\mathrm{B}$, we find that the rate of increase for $\mathrm{A}$ and $\mathrm{B}$ are as follows: $\mathrm{A}, 0.002 \mathrm{I} \times 10^{-6}$ per hour; $\mathrm{B}, 0.0018 \times$ ${ }^{10^{-6}}$ per hour. Comparing this with the results of Table 6 , where the silver was deposited on the platinum, we find-I, o.IOI $\times 10^{-6}$ per hour; II, $0.092 \times 10^{-6}$ per hour. That is, when the silver is 
deposited on platinum it affects the conductivity of the water at least 50 times as fast as when the platinum is absent. Probably the effect is very much greater than this, since one may reasonably say that the increase in conductivity of the water standing on silver in the beakers is due largely, if not entirely, to dissolved substances from the glass and the contamination by the air. In any case, the observed differences are large enough to be unmistakable.

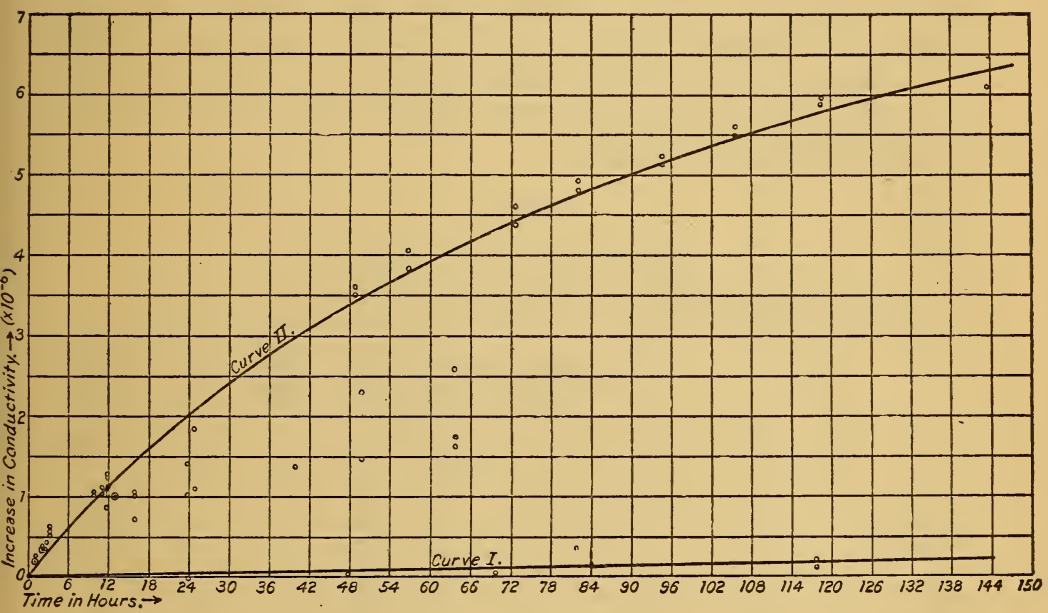

FIG. I.-Curve I shows the negligible increase in conductivity of water standing on silver in a beaker compared with the increase in conductivity of water standing on silver deposited on platinum, as shown by Curve II

Curve II of Fig. I shows the increases in conductivity of the water plotted against time for all cases in which the water stood on a four gram deposit of silver in a platinum or gold cathode. (See Table 8.) The various points are results for various deposits in various experiments and made under widely varying conditions. In some cases the deposits had been dried and weighed before the deposits were put to soak in water; in other cases they were not. In some cases the results are for the third wash water and in others for even the twelfth. Consequently, it 
is not surprising that the points do not lie more closely to the curve. We do not wish to lay emphasis on the position or form of the curve as we have drawn it, for this may be open to question, but the one fact that deserves attention is that all the results unite in showing that the conductivity of water standing on silver deposited in platinum increases at a much greater rate than when the water is standing on silver in a glass vessel.

We give in Table 8 complete data from which curve II in Fig. I is plotted. All the conductivities were measured at room temperature, which averaged about $23^{\circ}$ and ranged from $2 \mathrm{I}^{\circ}$ to $25^{\circ}$. Since we were primarily interested in the increases of conductivity rather than the absolute conductivities, the corrections for temperature are negligible.

\section{TABLE 8}

\section{Conductivities of Wash Waters}

[Nos. 27 and 28 are Bureau of Standards voltameters; I and II are Princeton voltameters]

\begin{tabular}{|c|c|c|c|c|c|c|c|}
\hline Date & Cup & $\begin{array}{l}\text { No. of } \\
\text { wash } \\
\text { water }\end{array}$ & $\begin{array}{c}\text { Duration } \\
\text { of } \\
\text { washing }\end{array}$ & $\begin{array}{c}\text { Ob- } \\
\text { served } \\
\text { con- } \\
\text { ductivity }\end{array}$ & $\begin{array}{l}\text { Conduc- } \\
\text { tivity of } \\
\text { water } \\
\text { initially }\end{array}$ & $\begin{array}{c}\text { Increase } \\
\text { in } \\
\text { con- } \\
\text { ductivity }\end{array}$ & $\begin{array}{c}\text { Deposit } \\
\text { pre- } \\
\text { viously } \\
\text { dried? }\end{array}$ \\
\hline 1914 & & & Hours & $\times 10^{-6}$ & $\times 10^{-6}$ & $\times 10^{-6}$ & \\
\hline \multirow[t]{2}{*}{ March $8 \ldots \ldots$} & 27 & 6 & $\frac{1}{6}$ & 1.05 & 0.98 & 0.07 & No. \\
\hline & 28 & 6 & $\frac{1}{6}$ & 1.00 & .98 & .02 & No. \\
\hline \multirow[t]{2}{*}{ March $21 . \ldots \ldots \ldots \ldots \ldots \ldots \ldots$} & 27 & 6 & 13 & 2.00 & 1.00 & 1.00 & No. \\
\hline & 28 & 6 & 13 & 2.00 & 1.00 & 1.00 & No. \\
\hline \multirow{2}{*}{ 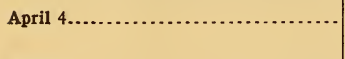 } & 27 & 5 & $\frac{1}{6}$ & 1.07 & .93 & .14 & No. \\
\hline & 28 & 5 & $\frac{1}{6}$ & 1.08 & .93 & .15 & No. \\
\hline \multirow{2}{*}{ April $5 \ldots \ldots \ldots$} & 27 & 6 & 12 & 2.01 & .93 & 1.08 & No. \\
\hline & 28 & 6 & 12 & 2.04 & .93 & 1.11 & No. \\
\hline \multirow{2}{*}{ Do................................... } & I & 7 & 10 & 2.09 & 1.06 & 1.03 & No. \\
\hline & II & 7 & 10 & 2.08 & 1.06 & 1.02 & No. \\
\hline \multirow[t]{4}{*}{ 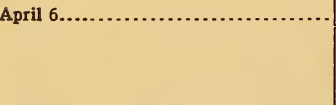 } & I & 8 & 12 & ..... & $\ldots$ & 1.23 & Nọ. \\
\hline & II & 8 & 12 & ... & & 1.02 & No. \\
\hline & I & 9 & 12 & & & 1.25 & No. \\
\hline & II & 9 & 12 & 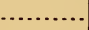 & & 1.08 & No. \\
\hline \multirow[t]{2}{*}{ 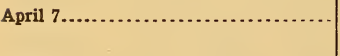 } & $I$ & 10 & $11 \frac{1}{2}$ & $\cdots$ & & 1.09 & No. \\
\hline & II & 10 & $11 \frac{1}{2}$ & $\ldots$ & 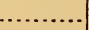 & 1.05 & No. \\
\hline \multirow[t]{3}{*}{ April $30 \ldots \ldots \ldots \ldots \ldots \ldots \ldots \ldots$} & 27 & 7 & $\frac{1}{12}$ & 1.10 & .96 & .14 & Yes. \\
\hline & 27 & 8 & $\frac{1}{12}$ & 1.09 & .96 & .13 & Yes. \\
\hline & 27 & 9 & $\frac{1}{6}$ & 1.06 & .96 & .10 & Yes. \\
\hline May $1 . . . . . .$. & 27 & 9 & 16 & 2.04 & .96 & 1.08 & Yes. \\
\hline \multirow[t]{2}{*}{ May $2 \ldots \ldots \ldots \ldots \ldots \ldots \ldots \ldots \ldots \ldots \ldots$} & 27 & 10 & 16 & 1.97 & .96 & 1.01 & Yes. \\
\hline & 27 & 10 & 24 & 2.36 & .96 & 1.40 & Yes. \\
\hline May $4 \ldots \ldots \ldots$ & 27 & 10 & 64 & 2.69 & .96 & 1.73 & Yes. \\
\hline May 5.... & 27 & 11 & 12 & 1.80 & .95 & .81 & Yes. \\
\hline
\end{tabular}


TABLE 8-Continued

Conductivities of Wash Waters-Continued

[Nos. 27 and 28 are Bureau of Standards voltameters; I and II are Princeton voltameters]

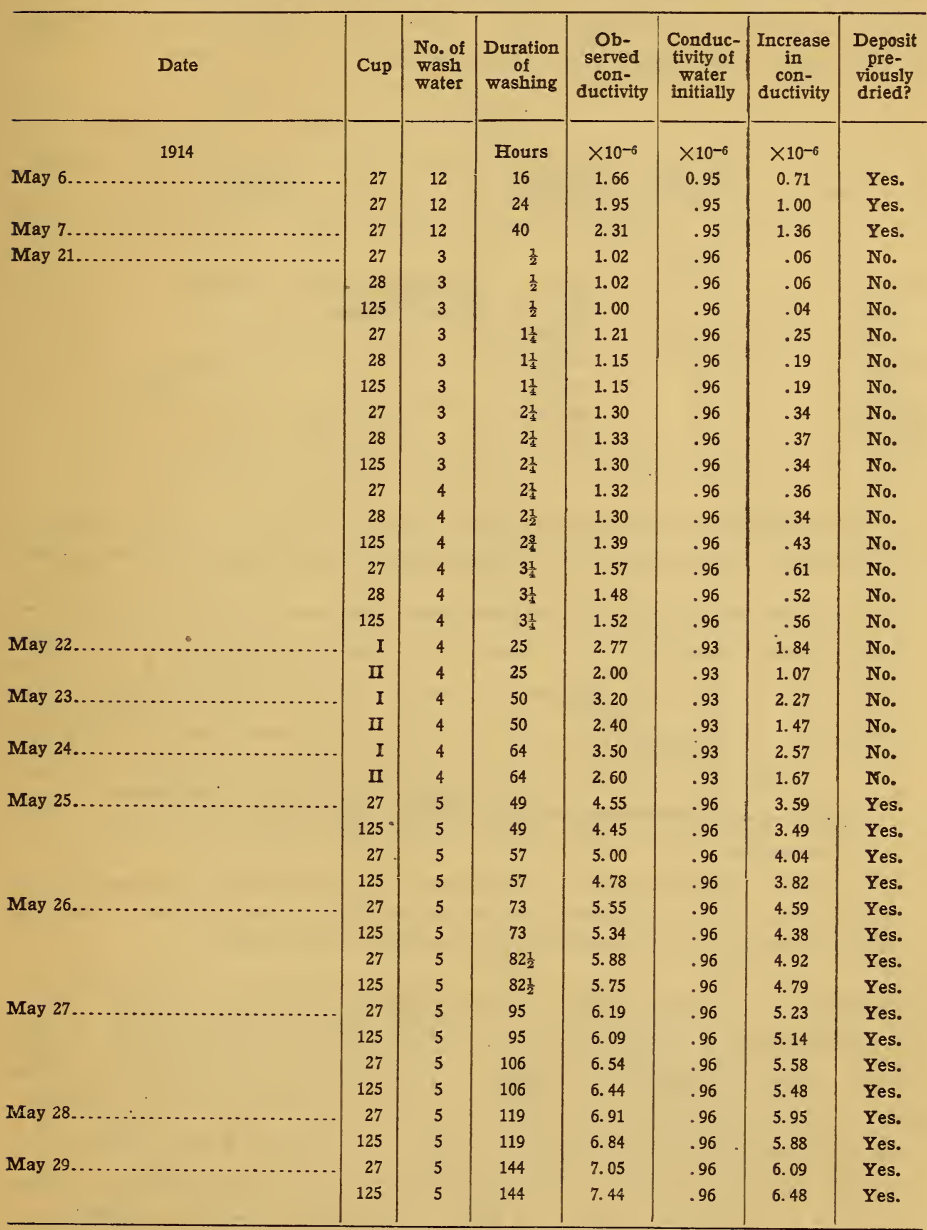

One might readily assume that this increase in conductivity of the water is due to entrapped silver nitrate soaking gradually out, 
in spite of the evidence on page 559 that the effect repeats itself indefinitely. We therefore took one of the sheets of silver used for the results recorded in Table 7 and put it to soak in conductivity water in a platinum cup. The silver rested on the bottom of the cup. The results are as follows:

TABLE 9

\begin{tabular}{|c|c|c|c|c|}
\hline Date & $\underset{\text { time }}{\text { Elapsed }}$ & $\begin{array}{l}\text { Increase in } \\
\text { conductivity }\end{array}$ & Remarks & \\
\hline 1914 & Hours & & \multirow{8}{*}{$\begin{array}{l}\text { Water in platinum cup. No silver. } \\
\text { Silver in the cup. }\end{array}$} & \\
\hline May 26.... & $21 / 2$ & None. & & . \\
\hline Do...... & $31 / 4$ & $0.06 \times 10^{-6}$ & & \\
\hline Do.... & $61 / 4$ & $.14 \times 10^{-6}$ & & \\
\hline May $27 . . . .$. & 19 & $.38 \times 10^{-6}$ & & \\
\hline Do.... & 30 & $.58 \times 10^{-6}$ & & \\
\hline May $28 . .$. & 43 & $.86 \times 10^{-6}$ & & \\
\hline May $29 . . .$. & 68 & 1. $40 \times 10^{-6}$ & & \\
\hline
\end{tabular}

These results are shown in the curve I of Fig. 2. For comparison we have also plotted the results when the sheets of silver stood

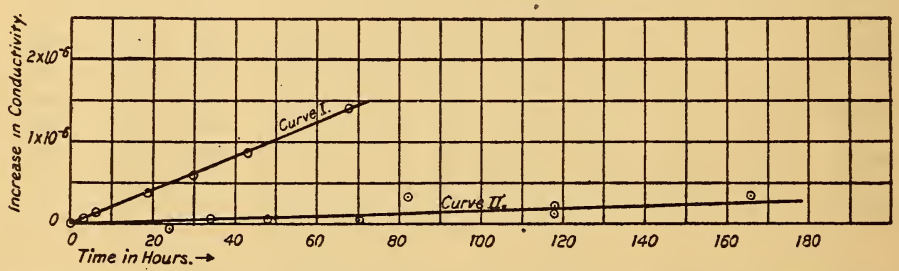

FIG. 2.-Curve I shows the increase in conductivity of water standing on a sheet of silver placed in a platinum cup contrasted with the negligible increase, shown by Curve II, when the sheet of silver and its duplicate were placed in glass beakers

similarly in a glass beaker. This is the same curve as I in Fig. I. The difference is smaller than is shown in the curves of Fig. r, but shows the effect quite certainly. To complete this test we boiled down the water that had stood on the sheet silver in a platinum cup and tested it chemically for silver. We found this solution to contain silver just as we had found in the case of the silver deposits referred to on page 560 . In this case there was no possibility of silver nitrate producing this effect. These results indicated an electrochemical action by which the silver passed into the solution. 
Accordingly, we made the following experiment to see whether evidence of an electric current passing from the platinum to the silver and into the water could be found. A platinum bowl filled with the best conductivity water was connected to the + terminal of a high-resistance potentiometer. In this and resting on the bottom was placed a sheet of silver (used in the experiments recorded above). This was connected to the negative terminal of the potentiometer. At a convenient time the silver was raised slightly and held in position in the water, but not in contact with the platinum cup. We then took the readings which are plotted

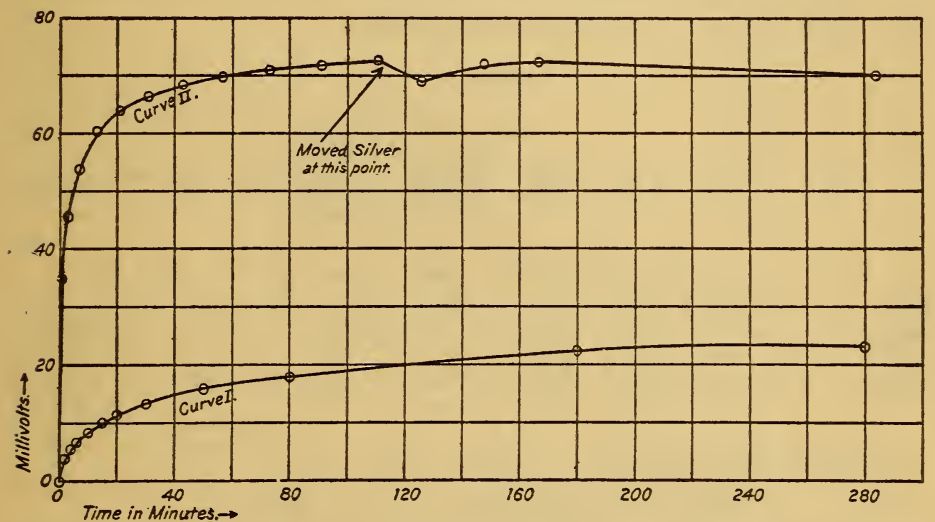

FIG. 3.-Curve I shows potential difference between a sheet of silver and the platinum cathode, the "electrolyte" being the best distilled water. The silver was raised to break contact with the platinum at time $t=0$. Curve II was obtained with a gold cathode

in the curve I of Fig. 3. Curve II shows a similar curve for a gold cup instead of the platinum. These results confirmed the idea that an electrolytic phenomenon was taking place. In a few cases we measured the loss of silver from the platinum bowl at the conclusion of the soaking process, either by estimating the silver in the water by the silver chloride produced by $\mathrm{KCl}$ after acidifying the solution or by reweighing the cup. We also tried estimating the silver by ammonium sulphocyanate, but without satisfactory results, because of the extremely small quantities involved. The results recorded below are not very concordant, but show that the 
losses of silver from the cathode bowl are about the same order of magnitude as the amounts of silver found in the water. If we take $0.006 \mathrm{mg}$ as the average amount lost to the cathode deposit per hour from $4 \mathrm{~g}$ of silver deposited on platinum, we see that soaking the deposit for one day of 24 hours means a loss of from 3 to 4 parts in 100000 of a 4 -g deposit, and that soaking the deposits overnight (about I 6 hours) quite certainly means a loss of 2 parts in 100000 of the deposit. In many cases the rate may be much greater than this, since probably a slightly higher conductivity in the water initially would increase the rate. Perhaps the reason that the effect seems greater at the start than after a long time is due to a gradual polarization.

TABLE 10

\begin{tabular}{|c|c|c|c|c|c|c|c|}
\hline Date & Cup & Hours & $\begin{array}{l}\text { Increase } \\
\text { in con- } \\
\text { ductivity }\end{array}$ & $\begin{array}{l}\text { (1) Loss of } \\
\text { silver by } \\
\text { weighings }\end{array}$ & $\begin{array}{l}\text { (2) Loss of } \\
\text { silver by } \\
\text { determina- } \\
\text { tion } \\
\text { of } \mathrm{AgCl}\end{array}$ & Ratio: $\frac{(1)}{\text { Hours }}$ & Ratio: $\frac{(2)}{\text { Hours }}$ \\
\hline 1914 & & & $\times 10^{-6}$ & $\mathrm{mg}$ & $\mathrm{mg}$ & & \\
\hline May $1 . . . . . . . . .$. & 27 & 16 & 1.08 & 0.21 & . & 0.013 & \\
\hline Maay $4 \ldots . . . .$. & 27 & 64 & 1.73 & .34 & 0.49 & .005 & 0.008 \\
\hline May $7 . . . . . . . . . .$. & 27 & 40 & 1.36 & . & .20 & $\ldots \ldots \ldots$ & .005 \\
\hline May $29 . . . . . . .$. & 27 & 144 & 6.09 & .67 & .52 & .005 & .004 \\
\hline Do............... & 125 & 144 & 6.48 & .64 & .53 & .005 & .004 \\
\hline $\mathrm{Me}$ & & & & & & .007 & .005 \\
\hline
\end{tabular}

Mean of all $0.006 \mathrm{mg}$ per hour from $4 \mathrm{~g}$ of silver on platincm.

This loss of silver during the washing of the deposits, of course, shows that the deposits should be washed and dried immediately.

One further point in this connection remained to be investigated. While it seemed fairly certain from the above experiments that an electrochemical action was taking place, there still remained the possibility that a little silver nitrate entrapped behind the crystals might be slowly soaking out and adding to the observed effects. Accordingly, we tried the following experiment: Two cups, No. 27 and No. I25, of the run of May 21 were filled with water for 144 hours while an exactly similar cup, No. 28 , remained dry. We scraped down half the silver deposit in No. 27 and No. 28 with a clean platinum spatula and then put $50 \mathrm{cc}$ of conduc- 
tivity water in each for five minutes to dissolve whatever $\mathrm{AgNO}_{3}$ might have been trapped between the crystals and the platinum. If the soaking process appreciably lessened the amount of $\mathrm{AgNO}_{3}$ entrapped, we should expect the conductivity of the water put in No. 28 to be increased more than that put in No. 27. The results given below show that this is not the case. To find what increase in conductivity of the water would take place, due to mere contact with the deposit not scraped down, we put 50 cc in No. I 25 for five minutes also. This affords a blank experiment, and the results are to be subtracted from those found for No. 27 and No. 28. The results are as follows:

Conductivity of water initially..................... $98 \times 10^{-6}$ at $22.5^{\circ} \mathrm{C}$ Blank experiment (water from No. I25) ................ I. $35 \times 10^{-6}$ at $22.5^{\circ} \mathrm{C}$ Increase to be subtracted from others......................... $37 \times 10^{-6}$ at $22.5^{\circ} \mathrm{C}$ Water from No. 27 , which was soaked for 144 hours ......... I. $56 \times 10^{-6}$ at $22.5^{\circ} \mathrm{C}$

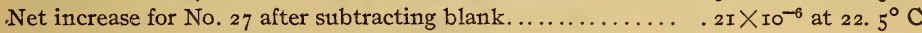
Water from No. 28 , which was not soaked............... $49 \times 10^{-6}$ at $22.5^{\circ} \mathrm{C}$ Net increase for No. 28 after subtracting blank........... $14 \times 10^{-6}$ at $22.5^{\circ} \mathrm{C}$

If we may assume that these small net increases for Nos. 27 and 28 represent silver nitrate trapped between the silver and the platinum, we may estimate the whole amount of such silver nitrate for each cup and find for No. 27, $0.03 \mathrm{mg}$; and for No. 28, $0.02 \mathrm{mg}$.

The conclusion of the whole matter is that prolonged washing of the silver deposits produces a measurable diminution in deposit, and it is therefore advisable that the deposits should be washed as speedily as possible.

\section{COMPARISON OF DEPOSITS ON GOLD AND PLATINUM CATHODES}

The Princeton gold cups are quite different in appearance from those of the Bureau of Standards. The former are more yellow than the latter, which have a greenish yellow appearance. It is believed that the Princeton cups are of the purer gold. These gold cups were compared in only the last two experiments, although one of the Bureau of Standards cups was used in several previous experiments for other purposes. The results are given 
in Table Io and show the substantial agreement of the deposits on gold and platinum cathodes of both the Princeton and Bureau of Standards voltameters.

TABLE 11

\section{Comparison of Gold and Platinum Cathodes}

[Nos. 27, 28, 125, and 126 are Bureau of Standards cups; I, II, III, and IV are Princeton cups]

\begin{tabular}{|c|c|c|c|c|c|}
\hline Date & Cup & Material & Deposit & Mean & Remarks \\
\hline $\begin{array}{l}1914 \\
\text { June } 19 . \ldots \ldots \ldots \ldots \ldots \ldots \\
\text { June } 23 \ldots \ldots \ldots \ldots \ldots\end{array}$ & $\begin{array}{r}28 \\
125 \\
\text { II } \\
\text { III } \\
27 \\
28 \\
125 \\
126 \\
\text { I } \\
\text { II } \\
\text { III } \\
\text { IV }\end{array}$ & 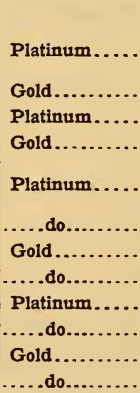 & $\begin{array}{c}\text { mg } \\
4113.29 \\
4113.27 \\
4113.31 \\
4113.37 \\
4133.56 \\
4133.53 \\
4133.62 \\
4133.58 \\
4133.60 \\
4133.47 \\
4133.69 \\
4133.52\end{array}$ & 4113. 31 & $\begin{array}{l}\text { Gold-platinum }=\frac{+0.5}{100000} \\
\text { Gold-platinum }=\frac{+1.5}{100000}\end{array}$ \\
\hline
\end{tabular}

Mean excess of deposits on gold over those on platinum is $\frac{1 .}{100000}$, which we consider excellent agreement.

These experiments do not explain the results of Dr. Buckner using the Princeton platinum and gold voltameters, where he found an excess of $\frac{12}{100000}$ in the deposits on gold over those on platinum. We are at a loss to assign a reason for the differences he found, since no such differences developed in our work, but we are inclined to the belief that the cause must have been in the electrolyte. We think that the fact that such a case may arise emphasizes the necessity of making the proposed international specifications rigid in requiring platinum cathodes, since that is the most generally used. 


\section{COMPARISON OF POROUS CUPS FROM DIFFERENT SOURCES}

The porous cups used in the Princeton voltameters were made by John Maddock \& Son, of Trenton, N. J., while those used by the Bureau of Standards in its previous work, and for the most part in the present work also, were made by the Königliche Porzellan Manufaktur, of Berlin, Germany. The American-made porous cups have a great advantage in having vitreous tops, but in their original condition they are too thick to be easily prepared for the voltameter. This difficulty was overcome by grinding down the sides and bottom with carborundum paper until the walls were about $\mathrm{I} \mathrm{mm}$ thick. Tests were made of the solubility of the porous material of both kinds of cups and these showed that after an initial washing to remove the free alkali, that the cups could stand for hours in double-distilled water without producing any significant increase in its conductivity.

In Table I I we give a comparison of results, using these two kinds of porous cups. This table contains all the comparative results in which the porous cups were prepared, as described in the Bureau of Standards Bulletin, 9, page 185 .

TABLE 12

\section{Comparison of Voltameters Using Different Makes of Porous Cups}

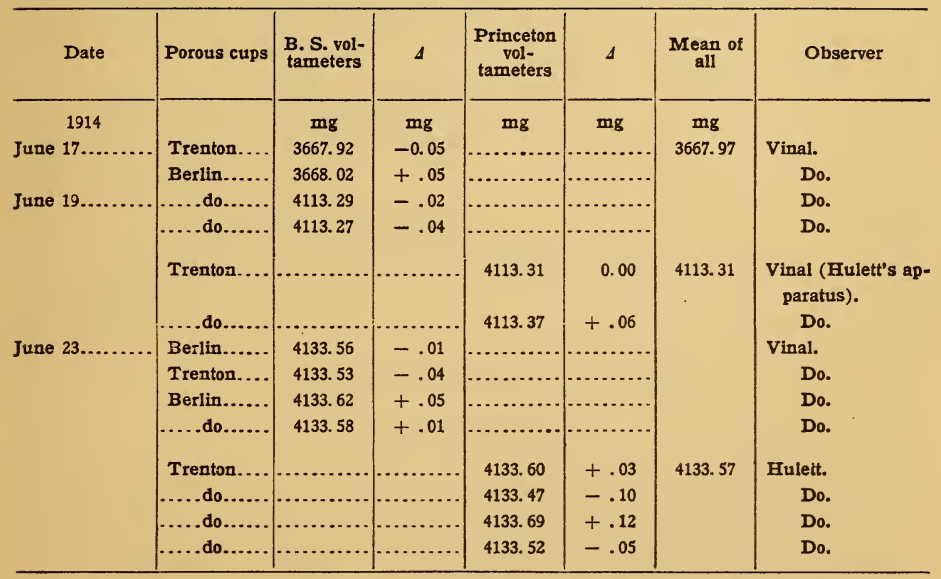

Average deviation of Berlin cups trom mean, $+0.007 \mathrm{mg}$; average deviation of Trenton cups from mean, $-0.002 \mathrm{mg}$. The agreement of results with these two makes of porous cups is very satisfactory. 


\section{SUMMARY}

We have made a comparison of porous-cup voltameters that differ considerably in size and shape and particularly in the manufacture of the porous cups. We find that when the porous cups are brought into equilibrium with the electrolyte, as shown by acidity tests, all the voltameters are in excellent agreement

We have found that when the voltameter cups containing deposits are allowed to stand filled with water (even conductivity water) a progressive solution of the silver takes place. That this is a galvanic action we have shown in several ways. The discovery of this effect makes it seem desirable to wash the deposits quickly.

Throughout the present work we have used methyl red as an indicator in the acidity measurements and have found it to be preferred to ideosine, because it is much simpler to use and at the same time gives sufficient accuracy.

Princeton, N. J., and Washington, D. C., July i, I9r4. 